\title{
THE VIRTUE OF COMPROMISE
}

\section{A VIRTUDE DO COMPROMISSO}

Yuval Eylon*

yuvaley@openu.ac.il

\begin{abstract}
Compromise is the virtue of political agents. This picture of the political is as common and familiar: politics is a realm where the reasonable, the compromising politicians get things done and the unreasonable and uncompromising are doomed to fringes. Thus, it is always right and reasonable make good compromises. The paper argues that under certain conditions, it is better and more effective to have non-compromising politicians. For example, think of a political party that every election moves towards the political center to maximize its chances of winning, but loses the elections at the cost of having the political center move further away from its original positions. If the process repeats itself, then a series of compromise would be disastrous, much as the considerations of the self-torturer are disastrous. Thus, there are systematic ways in which the reasonable compromises of a virtuous politician are sometimes (ultimately) unreasonable. Political virtue is all too often self-defeating, and therefore a curse in disguise.
\end{abstract}

Keywords: Compromise, self-torturer, virtue, political virtue.

Sumário. O compromisso é a virtude dos agentes políticos. Esta imagem do político é comum e familiar: a política é o domínio onde os políticos razoáveis e capazes de chegar a compromissos resolvem problemas, e onde os políticos pouco razoáveis e não dispostos a chegar a compromissos são relegados para as margens. Assim, é sempre correcto e razoável chegar a bons compromissos. Neste artigo, argumento que, sob certas condições, é melhor e mais eficaz ter políticos que não fazem compromissos. Por exemplo, pensemos num partido político que a cada eleição se move mais para o centro do espectro político para maximizar as suas probabilidades de ganhar, mas perde as eleições e isto à custa do crescente distanciamento do centro político em relação às suas posições originais. Se o processo se repetir, então uma série de compromissos seria desastrosa, tanto quanto as considerações do auto-torturador são desastrosas. Assim, há algumas formas sistemáticas através das quais os compromissos de um político virtuoso não são (em última análise) virtuosos. Frequentemente, a virtude política é autodestrutiva, e é por isso uma maldição disfarçada.

Palavras-chave: Karl Polanyi, Friedrich Hayek, safety net, pauperism, liberal creed. 


\section{Introduction: in praise of compromise}

Compromise is the virtue of political agents. This picture of the political is as common as it is familiar: politics is a realm where the reasonable and the compromising rule and the unreasonable and uncompromising are doomed to fringes. This piece of conventional wisdom is famously summed up by Bismarck's often quoted dictum - "Politics is the art of the possible, the attainable - the art of the next best". The saying is an apparent truism: It is always right and reasonable make good compromises, because a good compromise is simply that which achieves the most from existing possibilities (May 2005). ${ }^{1}$ Thus, the virtuous politician is the politician that has mastered the art of the possible, the attainable, even if this means a willingness to compromise various principles, ideals, values, or even allies. Indeed it might come to be that the best course of action dictates adopting a compromise that is a far cry from what was originally sought, perhaps even proclaimed and publicly committed to.

My aim in this paper is to argue that sometimes, the road to hell is paved with good compromises. In other words, that (in certain types of circumstances) it would better and all things considered more effective to have non-virtuous and politicians. The claim is not the observation that sometimes even the best politicians fail, but rather that there are systematic ways in which the reasonable compromises of a virtuous politician are sometimes (ultimately) unreasonable. In other words, political virtue is all too often self-defeating, and therefore a curse in disguise.

The view that compromise is a political virtue, if not the political virtue, applies to different types of political activities and actions. From the straightforward deal struck in backrooms negotiating support for a proposed law, to developing a platform prior to an election campaign that will appeal to many voters, to striking deals with different voter groups. As a matter of fact, it is hard to conceive of any area of political activity in which compromise is not required.

\footnotetext{
${ }^{1}$ May argues that compromises are never good simply because they are compromises, irrespective of their consequences. I will not take a position on this issue here. In what follows it is assumed that a good compromise is good because it is a preferable course of action irrespective of its being a compromise.
} 
What does the virtue of compromise consist in? I shall not attempt a full response to this question here, but a preliminary sketch of a response might mention in addition to a willingness to make concessions regarding principles, ideals, values and allies also what is involved in identifying, making - as well as publicly justifying - reasonable compromises: sound judgment and assessment of risks and opportunities, matching available means to achievable ends, addressing public opinion, appealing to it and if necessary challenging it, and so forth. In particular, the virtuous politician has the ability to strike a deal, the right deal, at the right time. This is probably universally true, but even more clearly so in democracies. Democracies come in different sizes and shapes - they have different structures, different electoral systems, a variety of political cultures. But whatever the system, building coalitions and bargaining are always a key, plausibly the key, to political success at every level of government.

The description of the virtue of compromise above comes close to a rough characterization of reasonableness in the realm of politics. This is hardly surprising, because a reasonable or virtuous politician must possess the virtue of compromise. In line with this, it is worth noting that that ordinary usage tends to assimilate the two virtues - and the requirement to "be reasonable" usually implies "make a compromise" or "do not be so stubborn (or dogmatic or "such a purist")" rather than the opposite (note the initial implausibility of something like "be reasonable - don't compromise!").

For our purposes it is not necessary to undertake the difficult task of disentangling the two virtues. Reasonableness in politics is more general, and includes more than the disposition to make a good compromise and strike a good deal, but I think it is not contentious that compromise is often a significant component of reasonableness. Thus, we can maintain that it is typically reasonable to make a good compromise, and that a reasonable politician also knows when a compromise is not available. In what follows I will treat the two together.

\section{The good and the Electable}

The very ideas of virtue in politics in general and of political virtue in particular, give rise to various puzzles. One important puzzle concerns the relation between the qualities required for getting elected into office, and those 
we expect from people who serve in office. Williams asked how can the good enough can rule the world as it is, and presented the conundrum thus:

It is widely believed that the practice of politics select's at least for cynicism and perhaps for brutality in its practitioners. This belief, and our whole subject, notoriously elicit an uncertain tone from academics, who tend to be either overembarrassed or under-embarrassed by moralising in the face of power. Excited, in either direction, by the subject, they often take rather large-scale or epic examples, such as the conduct of international relations by hostile powers, or ruthless policies which may or may not be justified by history. I will touch marginally on those kinds of issue at the end, but my first concern is more with the simply squalid end o f the subject, and with the politician not so much as national leader or maker of history, but as professional. I shall defer the more heady question of politicians being criminals in favour of the more banal notion that they are crooks (Williams 1981, 55).

What concerns Williams in this passage is the wide gap, even schism, between what it takes to get into office, and what we can expect - even reasonably and realistically expect - from those holding office. Initially, the problem inherited from Plato is how can the morally virtuous rule. And it is here that the schism Williams mentions is at its widest. One way of narrowing the gap is of course to allow for a conception of political virtue that falls short of moral virtue. But as emerges later in his paper, even this resolution of the conflict will not suffice - there is a real tension between what we expect - what we need - from those who rule, and what it takes (sometimes) to rule.

The important thing to note is that as Williams highlights, we are dealing with a structural problem - the need for procedures to select and elect politicians in way that reflects popular will leads to the selection of different qualities from those needed to rule, at least to some extent. The problem arises from the dual requirement made of politicians - to get into office, and to actually hold it. The difficulty in designing a system in which the former selects for the latter is a persistent problem of political philosophy.

It is also clear that resolving, or more realistically alleviating, this problem, requires a mix of institutional design and actual ongoing political engagement and advocacy, a s well as - per Williams' suggestion - changes in our political 
culture. In particular, Williams suggests that we should recognize the fact that politics is a career, learn to acknowledge and respect the achievements of politicians whose career does not take them to absolute top, and recognize the legitimacy of personal interests and considerations, within reason, during the course of a political career. These suggestions are not merely practical (inasmuch as they are), but reflect an amended and more nuanced view of political virtue, which is richer because it encompasses more than the short questions of who can to get elected and who can rule well, and adjusts the conception of political virtue to suit political agents living a political life.

\section{Chicken}

A different problem with political virtue bears directly on the virtue of comprising. Game theory as well as common sense suggest that in some situations it is preferable to be perceived as unreasonable and non-compromising (Russell 1959). One well known such scenario is the game of "chicken", in which two parties are on a collision course, and the first to swerve away loses (but survives). In such a game, if one party creates the perception in the other party that it will never swerve no matter what, then this gives them an advantage and forces the other side, if rational, to swerve (Schelling 1980). Therefore, in chicken-like scenarios, there is clear advantage in being perceived as unreasonable.

If actually being unreasonable and non-compromising are conducive, or sometimes even necessary, for the creation of such a perception, then we have an argument to the effect that unreasonable politicians - even outright stubborn and irrational politicians - are preferable as office holders in situations in which chicken-like scenarios are likely.

This problem can also be seen is an complementing Williams' problem: compromise is typically required in order to get into office, but in chicken-like scenarios non-compromise is sometimes needed in order to effectively or better serve in office. This points to a further instability within the idea of political virtue. Whereas in Williams scenarios virtue got in the way of getting elected but was needed in order to rule, chicken scenarios suggest the opposite is also a problem - when it comes to compromise, it might be necessary to get elected, but can sometimes hinder the ability to rule. At any rate, it seems that the qualities 
needed in order to excel as politicians in different circumstances vary greatly, and are arguably psychologically incompatible with each other - e.g., compromise and apparent unreasonableness.

The argument from the chicken-scenario to the conclusion that an uncompromising nature is superior in rulers was based on the assumption that typically, in order to create a perception of unreasonableness, genuine unreasonableness is required. An impasse seems inevitable, since the some aspects of office require reasonableness and compromise, and others unreasonableness and noncompromise.

However, all is not lost. The problem calls for an institutional solution: red limes can be backed by institutions designed to uphold them (Schelling 1963, Quinn 1990). A paradigm example would be an automated defense system programmed to launch a nuclear response if it detects any enemy attack. If such a system is known to be in place and it is known that response is guaranteed if a red line is crossed, then presumably a credible threat is created. Examples are not confined to automated systems and can include various institutions whose function and ethos are structured around response. Thus, a punitive system designed to respond when certain lines are crossed (with zero tolerance, absolute liability, etc,) can function as well to create the presumably required unreasonable and noncompromising perception of the penal system. The same holds for a military establishment. In such cases, the existence of institutions that "take care" of the creation of the required perception means that unreasonable rulers are not required (or not as required). This allows for a return to a more stable conception of political virtue that does involve reasonableness and compromise.

The significance of separation between the reasonable ruler and the unreasonable response is demonstrated by nuclear deterrence: arguably the threat of mutual destruction prevented war, although if war was to break out it would have been irrational to use nuclear weapons, even as a last resort. This tension is utilized by Arthur C. Clarke in the short science fiction story The Last Command (Clarke 1973). In the story, the crew of a nuclear space station, which is part of a second strike capability designed to ensure the enemy never launches a nuclear strike, receives the signal that nevertheless, war has broken out. The 
leader is heard in a recorded message explaining that if they hear this message, then the country has been wiped out. The deterrent has failed. However, the leader orders the crew not to fire the missiles in retaliation, because destroying what is left of the world would be "unworthy of reasoning men", and instead surrender to the enemy (i.e. to the president of the United States).

In summary, thus far we have looked briefly at two paradoxical or quasiparadoxical issues that threaten the conception of political virtue - Williams' claim that those fit to rule are unlikely to get elected, and the game theoretical scenario in which those unfit to rule are likely to rule more effectively than those who are fit to rule.

\section{The Virtue of Compromise and Dirty Hands.}

Let us set aside the problems discussed above, and return to the virtue of compromise and our starting point, which is the claim that the compromising politician is the politician that identifies reasonable compromises and is capable of making and publicly justifying them. We must guard against vicious circularity here: it is assumed that we have some grasp of what is involved in being reasonable which is not reduced to simply defining "the reasonable person" as someone who makes the reasonable or right compromises.

We can recognize in the compromising person modes of reasoning, temperament, non-dogmatic outlook, sensitivity to reasons in general, and sensitivity to the features of a particular situation as well as not being overly zealous in adhering to over-arching principles while remaining committed to them. The key is the ability to judge and act in a given situation, and not follow any pre-set pattern.

Broadly speaking, the virtue of compromise is a mean, flanked by the cynicism of the unprincipled political operative on the one extreme, and the overattachment to principles, ideals, or commitments of the purist or dogmatic ideologue at the other extreme.

Thus, at one extreme, we have the cynical politician. This person is all too familiar, and represents a temptation that politicians supposedly find hard to resist. There are two things to note here. First, that what defines the cynical politician is a lack of commitment to principles, ideals, promises etc. If and when 
called upon to justify their actions, such politicians are liable either to adopt the language of necessity - claiming that they have made a necessary albeit painful compromise, or as Williams has pointed out, appeal to grand over-arching justifications (Williams 1981, 62).

The second important feature is that commonly such politicians are treated as if they prioritize their personal interests in advancing their careers over the public good. Arguably, this picture is exaggerated, and is the result of media focus on the personal rather than the ideological, and a tendency to depict political contests as sporting dramas. Contrary to this cynical view, it might argued, even in pursuit of what seem to be personal ends, politicians are typically committed to some world view and it is all easy to depict the compromises - the good and necessary compromises and not only the bad and opportunistic compromises - as cynical and unprincipled.

This objection to the depiction of politicians as an immoral and self-serving lot has some force. Nevertheless, even the staunchest advocate of present day politicians and political culture must surely concede that there is at least more than a kernel of truth here, and that pursuit of personal ends often takes priority over commitments to the public good. I will return to this tension between the good of politicians and (some versions of) the public good below.

At the other extreme we have over-commitment. This is the sin of of being blindly committed to principles, ideals, previous commitments, etc. "at all costs" and ignoring contingencies and consequences. We can perhaps distinguish here between two related vices: dogmatism - an unyielding commitment to principle and purism, which is an commitment to moral purity, or to clean hands, and is thus more self-directed. ${ }^{2}$

This sketch of the virtue of compromise highlights the tension between commitment to principles as well as ideals and some long term interests, and between consequences and in particular short term consequences (as well as some long term consequences). However, unlike the problem of dirty hands, the tension extends beyond moral principles to ideological commitments, ideals,

\footnotetext{
${ }^{2}$ The idea of the politician as making a moral self-sacrifice is presented in Waltzer (1973). This possible view of dirty hands places the morality of the agent as the focus of the political vocation.
} 
political principles, political promises, and alliances. All of these are liable to be compromised if and when the opportunity (or need) arises.

This also means that the vices of compromise, or the cost of compromise, does not always involve the kind of moral cost or even sacrifice that Waltzer (1973) associates with dirty hands. A political comprise can be costly, psychologically difficult to undertake, disappointing, and so forth - without being morally costly in the sense of being straightforwardly morally wrong or in violation of a moral principle.

\section{The Self Torturer}

Reasonable compromises can sometimes fail. There is no mystery here, and this is of course only to be expected, as even the best laid schemes of men often fail. But the problem I will present is that there are systematic ways in which the reasonable compromises of a virtuous politician are, all things considered (in a sense that will become apparent) - not effective and this sense unreasonable. The problem resembles the problem of the self torturer introduced by Warren Quinn (1990):

Suppose there is a medical device that enables doctors to apply electric current to the body in increments so tiny that the patient cannot feel them. The device has 1001 settings: o (off) and 1 ... 1000.1 Suppose someone (call him the self-torturer) agrees to have the device, in some conveniently portable form, attached to him in return for the following conditions: The device is initially set at $\mathrm{o}$. At the start of each week he is allowed a period of free experimentation in which he may try out and compare different settings, after which the dial is returned to its previous position. At any other time, he has only two options -- to stay put or to advance the dial one setting. But he may advance only one step each week, and he may never retreat. At each advance he gets $\$ 10,000$. Since the selftorturer cannot feel any difference in comfort between adjacent settings, he appears to have a clear and repeatable reason to increase the voltage each week. The trouble is that there are noticeable differences in comfort between settings that are sufficiently far apart. Indeed, if he keeps advancing, he can see that he will eventually reach settings that will be so painful that he would then gladly relinquish his fortune and return to 0.2 The self-torturer is not alone in his predicament. Most of us are like him in one way or another. We like to eat but 
also care about our appearance. Just one more bite will give us pleasure and won't make us look fatter; but very many bites will. And there may be similar connections between :puffs of pleasant smoking and lung cancer, or between pleasurable moments of idleness and wasted lives.

The problem of the self-torturer is a problem of practical rationality - it arises from what appear to be rational choices in individual cases, but which create a problematic pattern and lead to undesirable consequences.

\section{Compromises}

Now let us consider a political party facing an election. The current leader of the party, and current candidate, makes a tactical compromise in addressing the voters in order to improve their chances. The candidate yields some ideological ground, compromising some principles and perhaps abandons certain arguments and key concepts in justifying proposed policies. Thus, the candidate "shifts to center", under the assumption that by doing so they will attract more undecided voters, while retaining the party's base.

Despite the protests of apparent purists or dogmatic supporters, the party's candidate has a convincing argument: the proposed compromise is necessary in order to increase the party's chances of winning the elections, and is the best political maneuver available, given the parties values, ideals, and aims. Let us assume also that there is no substantial disagreement about what these values, ideals and aims are, or about their relative significance.

Suppose further that despite its efforts, the party fails to win the elections. However, in adopting the compromise it ceded political ground - important principles, key concepts and modes of justification - to its rivals, and the whole political map has shifted away from its core values towards the other end of the political spectrum. Thus, the imaginary center of the political spectrum has shifted as well.

In the next elections, this choice repeats itself and a pattern is created - a new candidate that replaces the failed candidate of the previous elections convincingly argues that in order to increase the party's chances of winning the elections it must shift its positions towards the (new) center in order to attract more voters while retaining its base, thus moving it even further from its core 
values and principles. Again, the argument is convincing and the party runs its campaign according to the proposed strategy. And again, our party fails to win the elections, and again the compromise leads to a shift of the entire political spectrum and the political center have even further away from the party's core values.

Suppose that this process repeats itself several times. Eventually, our imaginary party runs the risk of losing contact with its original values, and cedes the political map to its rivals. What this means is that a series of rational and justified compromises can lead to a loss of integrity - to giving up core positions and values. Furthermore, it can lead to an ultimate compromise that in advance is clearly unreasonable according to any of the interested agents. 3

At this point one might protest that if we take into account such long term effects as ceding political ground, then in cases in which they such effects are likely the compromise is not reasonable. A compromise is reasonable if and only if the long term damage is outweighed by the short term advantage compromise just failed as sometimes if the case, so if this outcome was likely then the compromise was unreasonable.

Here, however, an agency problem raises its head. The biconditional tacitly attributes the decision to compromise, and the virtue of political compromise, to an abstract agent that personifies the political party or political camp. Indeed, from the perspective of the party or of a spectator who is committed to the value and ideals of this party and taking into account the likely consequences, such a compromise would seem wrong.

But the decision to compromise and virtue of compromise do not belong to abstract political parties or to spectators, but to real agents - individual politicians, or arguably collective agents. And the interests - the legitimate interests - of individual politicians do not match those of the parties they belong to or lead. If we allow, as Williams implores us to, that politics is also a career and not only a calling, and that politicians can and should give some weight to their

\footnotetext{
${ }^{3}$ Note that this does not require a change of preferences. We can postulate that the outlook of the party members has remained unchanged throughout the series. Nevertheless, each compromise seems reasonable at the time it is made. Thus this version of the problem resembles the self-torturer more than those presented by Elster (1984).
} 
own personal interests, then the picture changes. The key claim is that it is reasonable enough for a politician that probably gets only one shot at winning an election, to compromise as in the abovementioned scenario.

Let us illustrate this claim with simple scenario. Suppose a candidate has a fairly small chance of winning an election, say around 20\%, and making a compromise of the kind alluded to above will increase these chances to $30 \%$ or even $35 \%$. For the candidate, it seems that there is no question what is the correct course of action. Furthermore, this is the course of action the candidate is expected to take, and that at least some party members expect.

Not so for actual party or political camp. Here, indeed, the long term harm mat well justify rejecting the proposed tactic and compromise. This is particularly true if in the longer term, only a more principled and persistent approach could lead to victory. Thus, ceding ground here has long term consequences that matter to the party and to some party activists but less so to the candidate and perhaps other party activists. Whereas the short term consequences maybe matter a lot to the party - they are everything to the candidate.

The commitment of the candidate to the short term is a matter of institutional design and political reality - the candidate is supposed to be invested in the short term, and try and win the present elections. This is heightened by a political climate in which candidates typically get only one opportunity - they typically get to lead the party only once, unless they win. In fact, if they lose their political career is probably over - thus rendering passing over the compromise political self-sacrifice.

Thus, it is reasonable for the candidate to make the compromise described above, in order to maximize their chances. Not only is this the candidate's only chance, but also it is important to note that the candidate in this scenario is not undertaking some "scorched earth" tactic that will leave the party in ruins if they fail. Indeed, the present compromise might cause some damage to the party, but this damage is not irreparable. Furthermore, the long term risk to the party, even if likely, is far from certain and it will be up to future candidates to stop the descent or alternatively win an election. This means that our candidate is not responsible, at least not fully responsible, for the entire possible chain of compromises. Thus, our compromising candidate is not a complete cynic who 
only interested in personal success, but a reasonable and virtuous career politician whose career and personal success do matter to him, and are on the line.

The key here is that we can distinguish, even within a political camp or party, between competing legitimate considerations and interests of different actors. Furthermore, arguably these might lead also to epistemicaly different perspectives, and thus e.g., to legitimate different perceptions of uncertainties.

\section{Imperfect Virtue}

If we allow that our conception of political virtue, and accordingly of the idea of a reasonable compromise, is sensitive to different interests of different stakeholders within a political body, then we risk that in relevant circumstances, reasonable compromises are prone to yield unacceptable consequences, and that thus reasonable politicians produce an unreasonable pattern of decisions.

When we encountered the related difficulty with the possibility that in scenarios that resemble a game of chicken, it might be overall more effective to have unreasonable leadership then reasonable leadership, it was suggested that the solution to the apparent difficulty lies in institutional design: creating mechanisms or institutions that enable decision makers to create red lines or deliver credible threats.

The crucial point here is that in the absence of such institutions, it is in the interest of the rulers themselves to create them and bring about a situation in which they exist, thus enabling them to rule more effectively. For example, this would mean that a ruler who is confronted with a crime wave and who believes that the threat of draconian punishments would help fight crime would have an interest to create a system that delivers severe punishments without discretion.

But our present predicament is more difficult to resolve, even in principle. The reason is that the problem in chicken-like scenarios is a problem for those who rule. They are at a disadvantage because they are perceived as reasonable and compromising. It is therefore in their interest to create mechanisms that change this perception - mechanism that can provide credibility to red lines and credible threats. A conflict between the comporting ruler and such a mechanism could arise only if the red line is infringed or the threat fails and the question of 
carrying it out arises. Put differently, the interest to create a perceived uncompromising response is designed to guarantee such a response will not be required. A conflict of interests would arise only if the threat failed to achieve its designated end. 4

Now let us suppose that in order to confront the problem of the serial compromises we introduce some measures such as a party constitution which lists its main principles, or a party court composed of its elders, or perhaps some other strong organs designed to embody and represent long term interests and more principled thinking. When election time comes around, these arrangements are liable, indeed likely, to stand in the way of what the party's candidates and those activists and groups that support them - interested in winning the elections and devoted to this task - will want to do.

This conflict of interests means that the candidates - the party's leadership - have a strong reason to work against such institutions: to oppose their creations if they do not exist, to oppose strengthening them if they are weak, to seek to weaken them if they are strong, and in general support their dissolution. This does not imply that some happy, or at least not too unhappy, balance cannot be maintained between candidates who are interested in short term success and institutions that cater for the long term and keep the candidates in check.

However, when such a balance or structure is lacking or is weak, it is not in the interests of the party leadership to introduce it or strengthen it. The case is quite the opposite. And since, ex hypotheses, this is the predicament in which we are in, there is scant hope of recruiting the leadership to promote a solution. Thus, whereas in the case of a game of chicken the apparent paradox can be mitigated if not resolved, in our case the conflict of interests between the short terms interests of the candidates and the long term interests of the party are not easily reconciled by institutional design. In fact, when suitable institutions are not in place, then eo ipso there is no recognizable agent that has an interest to bring them into being.

\section{The Tragedy of Greece}

\footnotetext{
${ }^{4}$ See Eylon (2009) for a discussion of threats and their function.
} 
Examples in which it is contended that political parties ceded essential ground by a series of compromise are fairly common, and I will not elaborate on such examples here. I want to mention a somewhat different case, one that demonstrates a different but related pitfall of a series of reasonable compromises. Namely, that of piecemeal erosion not so much of the ideology of a party or its avowed principles, but a similar process that led to the erosion of its motivation to act and political ability to do so. This apparent erosion involves and is the consequence of further structural factors, different from those that give rise to the need for compromise in our hypothetical elections example above.

Let us look very briefly at Yanis Varoufakis' Adults in the Room (2017): his account of the struggle during 2015 to save Greece from the austerity regime imposed on it. I will not question the account presented in the book, but accept it for argument's sake an accurate representation of events. The book recounts the events from January to late August 2015: from Syriza's winning the elections and forming a government with Varoufakis as Finance Minister on the basis of a promise to combat the debt settlements and austerity policies imposed on Greece, to the government's decision to ignore the clear outcome of the July referendum on the Eurogroup's proposal, and accept the proposal.

According to Varoufakis, his strategy in dealing with the debtors was based on the idea that a new and sufficiently improved debt agreement was preferable to withdrawing from the Euro, which in turn was preferable to an agreement resembling the old debt agreement and imposing further austerity of Greece. He believed that the only way to reach an improved deal was to credibly threaten to withdraw (Varoufakis 2017, 108).

In a nutshell, my claim is that the problem with the strategy was that during this period the Greek government faced a series of choices in which they either could quit negotiations and plausibly quit the euro, or continue despite being snubbed and thus also allow the forces that opposed quitting to gain ground. Invariably, the Greek government chose the latter at every junction, and thus undercut its ability to withdraw from the euro, which was an option they initially preferred to continuing with the original settlement.

The book, as Varoufakis himself states, is a testimonial - an account provided by a participant turned witness, who apparently us utilizing his skills 
and training as an academic to provide an accurate and as objective as can be expected account of events. Importantly, Varoufakis himself views being in the position to provide this eye-witness account a possible justification of his own decision to enter politics.5 In this respect, the book is presented to us as redeeming - even if he failed to deliver Greece from its predicament, the attempt to do so enabled Varoufakis to expose the troika and perhaps lay the foundations for a more successful attempts in the future.

In addition to recounting the events and providing a glimpse into the workings of power in general, and the workings of the EU in particular, the book attempts to explain and asses the events that led to the rejection of the results of the referendum and ultimately to Varoufakis' resignation. Herein lies the book's real purpose, as an apologia. Ultimately, Adults in the Room is the argument for the defense of what Varoufakis himself considers to have been a failed attempt to improve the terms of the debt relief imposed on the Greek people.

It is this context that Varoufakis turns to tragedy - in particular Shakespearean tragedy - to provide the moral framework of his account. Varoufakis' account of events turns, ultimately, on the personal weaknesses of his colleagues and partners in government. Whereas the actions of actors such as Lagarde (then at the World Bank) or Shwable (Varoufakis' German counterpart) or Social Democratic supposed prospective allies such as Hollande, are explained by various structural and circumstantial causes (p. 29), those of the Greek politicians and government are also accounted for, at least in no small part, by character and individual psychology. It is here that Varoufakis' many references to Shakespearean tragedy come to the fore - relating the unfolding events to the tragic flaws of various protagonists.

This in evident in particular the subsection entitled "Gazing into an abyss: comrades in retrospect" (pp 457-461) in which Varoufakis sums up both the fatal weaknesses of, e.g., Prime-minister Alexis Tsipras, as well as those character traits that account and justify having trusted him: "His desire to liberate Greece [...] was there. His intelligence and capacity to learn quickly were self-evident.

\footnotetext{
5 See in particular (Varoufakis 2017, 8), in which Varoufakis concludes a meeting with Larry Summers with the claim that if politicians fail him, he will turn whistle-blower.
} 
His enthusiasm for the deterrent I had proposed and the debt relief [...] was real [...] When he had instructed me, in front of our cabinet, to fly to Washington to tell Christine Lagarde we were going to default, the enthusiasm had been authentic." (p. 457) It was only after what he describes surrender under pressure and embracing "big brother" (p. 461) that Varoufakis realizes that "My mistake was to miss other things that were bundled up with them: his back-up plan, which would inevitably annul my work; his frivolity; his tendency to melancholy; and lastly his intense desire to prove to a skeptical world that he was no shooting star." (p. 457)

Varoufakis' narrative is an ethical one and it places ethos at the center of human life, supposedly revealing the lack of character and backbone of his partners. First and foremost in this list of flawed characters is Prime Minister Tsipras. Greatly oversimplified, the narrative boils down to this: after the rejection of all offers to improve the deal, and following the referendum in which the Greek people unequivocally voted to reject the proposed settlement, the government caved in and capitulated. The reason for this decision lay in the lack of moral fortitude, and lack of respect to the verdict of the public. Thus, at the heart of a detailed account of the forces in play and of the economic, political, and ideological pressures and realities, we find a morality tale.

\section{The Fault lies in Our Stars}

In what follows I suggest there is a different possible lesson from the chronology of events as presented by Varoufakis, namely, that the problems Varoufakis' strategy ran into are primarily structural, and that these structural issues present a problem to the idea of the virtues of compromise and reasonableness. The problem is related to that of chicken-like scenarios, but mainly it is a problem of the erosion and processes that might occur as the result if a series of reasonable compromises.

As claimed above, Varoufakis' strategy was based on the following contention: there are three possible outcomes of the negotiations between the new Greek government and the Troika, ranking from best to worst:
A. An improved settlement
B. Quitting the euro 
C. Accepting the current proposed settlement.

Varoufakis wanted to achieve A, and believed that A was achievable. His claim was that A could be achieved only if Greece could make a credible threat that if forced to choose, it would opt for B rather than C. If it could make such a threat, Varoufakis believed, the Troika would also prefer A to B as it was clearly in their respective interests.

This general scheme raises two problems we have been discussing. First, the threat to adopt B unless A has to be a credible threat. In particular, if it is perceived (by the troika) to be an unreasonable course of action - e.g., as politically suicidal, the threat would not deter anyone. Thus, some measures must be taken in order to create the perception that indeed Greece would opt for $\mathrm{B}$ rather than $\mathrm{C}$.

The second problem is that if one fails to achieve A, then B must indeed be adopted in order to avoid C. However, it is possible that the strategy aimed at achieving A will create the conditions that ultimately led to adopting C over B.

First, the situation and strategy adopted by the Greek government rested on the assumption that taking option B would seem and appear to be a viable option. To this, certain preparatory steps were taken or supposed to be taken. It is important to note that these steps were not always completed, and at least in some cases they were actively frustrated. Thus, crucially, the type of mechanism that is required in order to create credibility was either completely lacking or at least fell short of grounding a credible threat. Arguably, the best way to create the perception of really preferring $\mathrm{B}$ over $\mathrm{C}$ and thus pursue A would have been to really begin a process of leaving the euro. However, according to Varoufakis himself, such preparations were constantly thwarted.

One important point that stands out in the account is that from the moment negotiations began, Varoufakis faced a lack of cooperation and repeated snubs by the troika. The relative lack of response to these snubs, could have produced a dual impact. First, it helped erode the perception that the threat to choose B over $\mathrm{C}$ if A were unavailable would be carried out.

Second, and more importantly, as each snub was countered by a further compromise and an attempt at making reasonable proposals and arguments, the 
resolve to pursue $\mathrm{B}$ and choose it over $\mathrm{C}$ by the government was eroded. This is not a psychological assessment of the personal will of ministers, although this might have played a role as well, but a claim about the political will of the government. There are multiple factors that can come into play: cooptation of certain actors, political rivalries, political pressure, ideological pressure, fear of change. It is here that we can view the months between taking office and Varoufakis' resignation as a period in which the idea and resolve to pursue $B$ eroded.

Thus, when it became clear that the troika will not yield, the government opted for a referendum on the proposal, under the assumption that the proposed settlement would be accepted. It is a testament of the either the erosion of political will, or an absolute reversal of priorities and preferring $\mathrm{C}$ to $\mathrm{B}$. In either case, the it is clear that the government was so committed to remaining that it decided to ignore the results of the referendum it itself initiated, when the position it supposedly supported was accepted. If this is indeed the result of processes that took place while in office, and if assume that the original ranking of options was correct, then it follows that it was better to commit to B as soon as possible and avoid the attempt to pursue A.

\section{Conclusion}

We started from the idea that compromise is the virtue of political agents. I argued that if we look at the problem of electing worthy politicians, and at chicken-like scenarios, then it transpires that the in certain conditions virtuous politicians and political virtue become a political liability. Whereas the problem Williams presented was between moral virtue (even reasonable moral virtue) and political virtue, the chicken-like scenarios undermine the idea of political virtue. However, both call for an institutional solution.

Following this claim, I have argued that political virtue can encounter an additional problem, and one that is less friendly to an institutional resolution. Namely, that a series of reasonable compromises can lead to unwanted consequences. Put differently, that a series of reasonable compromises can turn out to be unreasonable. 
This problem, if it arises, becomes especially stubborn because unlike in the chicken scenarios, the most powerful political agents have an interest to oppose any institutional solution, and might aim to aggravate the problem. This suggests that our conception of political virtue requires broadening to include politicians that are typically more principled than has been assumed in this article, or perhaps that a plurality of characters is an essential requirement of politics.

\section{References}

Clarke, A. C. (1973). The Last Command. In Clarke, A. C., The wind from the sun (p.61-62. New American Library.

Eylon, Y. (2009). Just threats, Journal of Moral Philosophy, 6 (1), pp 94108.

Elster, J. (1984). Ulysses and the Sirens, rev. ed. Cambridge: CUP.

Margalit, A. (2009). On compromise and rotten compromises. Princeton University Press.

May, S. C. (2005). Principled compromise and the abortion controversy. Philosophy \& public affairs, 33(4), 317-348.

Quinn, W. S. (1990). The puzzle of the self-torturer. Philosophical studies, 59(1), 79-90.

Russell, B. (1959). Common sense and nuclear warfare. George Allen and Unwin.

Schelling, T. C. (1980). The strategy of conflict. Harvard university press.

Varoufakis, Y. (2017). Adults in the room: My battle with Europe's deep establishment. Random House.

Walzer, M. (1973). Political action: The problem of dirty hands. Philosophy \& public affairs, 160-180.

Williams, B. (1981). Politics and moral character. In Williams, B., Moral luck: philosophical papers 1973-1980 (p.54-70). Cambridge University Press. 